This item was submitted to Loughborough's Research Repository by the author.

Items in Figshare are protected by copyright, with all rights reserved, unless otherwise indicated.

\title{
Grounding-zone wedges on the northern Larsen shelf, Antarctic Peninsula
}

PLEASE CITE THE PUBLISHED VERSION

http://dx.doi.org/10.1144/M46.3

\section{PUBLISHER}

(c) Geological Society of London

\section{VERSION}

AM (Accepted Manuscript)

\section{PUBLISHER STATEMENT}

This work is made available according to the conditions of the Creative Commons Attribution-NonCommercialNoDerivatives 4.0 International (CC BY-NC-ND 4.0) licence. Full details of this licence are available at: https://creativecommons.org/licenses/by-nc-nd/4.0/

\section{LICENCE}

CC BY-NC-ND 4.0

\section{REPOSITORY RECORD}

Evans, Jeff, and K.A. Hogan. 2019. "Grounding-zone Wedges on the Northern Larsen Shelf, Antarctic Peninsula”. figshare. https://hdl.handle.net/2134/16915. 


\title{
Grounding-zone wedges on the northern Larsen shelf, Antarctic Peninsula
}

\author{
J. EVANS ${ }^{1} *$ \& K. A. HOGAN ${ }^{2}$ \\ ${ }^{1}$ Department of Geography, Loughborough University, Loughborough LE11 3TU, UK \\ ${ }^{2}$ British Antarctic Survey, High Cross, Madingley Road, Cambridge CB3 OET, UK \\ *Corresponding author (e-mail: j.evans2@lboro.ac.uk)
}

Prominent quasi-linear or lobate wedge-shaped depositional sedimentary landforms, termed grounding-zone wedges (GZWs), are distributed widely on polar continental shelves. They are regarded as a product of the deposition of mainly subglacially-transported sediment at the grounding-zone of modern and palaeo ice sheets and ice streams (e.g. Shipp et al. 1999; Ottesen et al. 2005; Horgan et al. 2013). GZWs vary in shape, dimensions and regional distribution across the continental shelf, where they can form single or multiple and widely- or closely-spaced depositional features. The presence of these landforms is used to delimit the maximum and retreat positions of former ice-sheet margins on high-latitude continental shelves (e.g. Shipp et al. 1999; Ottesen et al. 2005). During the Late Glacial transition, retreat of the Antarctic Peninsula Ice Sheet that covered the shelf of the NE Antarctic Peninsula during the Last Glacial Maximum (LGM) produced several distinctive grounding-zone landforms (Evans et al. 2005).

\section{Description}

Well-defined ramp-scarp, wedge-shaped bathymetric features on the seafloor are present in several places across the northern Larsen shelf south of Larsen Inlet and east of the deepest part of Greenpeace Trough, NE Antarctic Peninsula (Fig. 1a-h). The landforms are found at water depths of 510 to $580 \mathrm{~m}$; they are spaced $\sim 6$ or more kilometres apart, are up to 15 to $20 \mathrm{~km}$ in length, 10 to $18 \mathrm{~m}$ in height, and several kilometres in width (Fig. 1a-g). The landforms comprise a flat area or ramped inner, landward-facing slope coupled with a steeper outer or seaward-sloping face or scarp that together form a wedge shape (Fig. 1 c-e). In some cases, the landforms are located on reverse bed-slopes linked to progressive inshore deepening of the shelf towards Larsen Inlet and inner Larsen-A (Fig. 1c-e). TOPAS sub-bottom acoustic profiler data indicate that the landforms are sedimentary and comprise acoustically transparent sediment beneath a thin surface sediment layer or drape (Fig. 1f, g). In planform, the landforms comprise numerous prominent curved or lobe-shaped and streamlined sections pointing in the outer-shelf direction, separated by quasi-linear sections (Fig 1a, b).

Mega-scale glacial lineations (MSGLs) are also present on the seafloor of Larsen Inlet and are orientated at right angles to the wedge-shaped bathymetric landforms (Fig. 1a, b). There is a discordant relationship between the two sets of landforms where: (i) MSGLs distributed on the inner flat or ramped sloping side facing Larsen Inlet terminate at, or a short distance from, the seafloor scarp (marked by red arrows in Fig. 1b); and (ii) MSGLs extend shelfward away from the base of the outer face of the seafloor scarp (marked by light blue arrows in Fig. 1b). The wedge-shaped landforms appear, therefore, to overprint the MSGLs (Fig. 1b).

\section{Interpretation}

The distinct ramp-scarp morphology of sedimentary landforms on the northern Larsen continental shelf, with their perpendicular orientation to, and overprinting of, MSGLs (Fig. 1ag), are interpreted as GZWs that are formed transverse to ice flow at the grounding-zone of an 
ice stream draining the former Antarctic Peninsula Ice Sheet (APIS) (Evans et al. 2005). The landforms are likely to have formed mainly as a result of the deposition of subglacially transported and deformed sediment that emerges at the ice-sheet grounding-zone on account of the widespread presence of a deformation till that appears as acoustically transparent sediment in TOPAS records (Fig. 1f, g), and their association with MSGLs (Fig. 1b) on the shelf both upstream and downstream of the landforms (Evans et al. 2005).

Similar sedimentary landforms, and their transverse relationship to subglacial bedforms and therefore to ice flow, have been observed on the formerly glaciated terrain of other Antarctic and Arctic continental shelves (e.g. Shipp et al. 1999; Ó Cofaigh et al. 2005; Ottesen et al. 2005), and at the grounding-zone of modern West Antarctic ice streams (e.g. Horgan et al. 2013). Overprinting of MSGLs by the GZWs indicates that the latter were formed during temporary stillstands, of perhaps decades to centuries (Dowdeswell \& Fugelli 2012), in the position of the grounding zone of the APIS during its last deglacial retreat towards Larsen Inlet and the inner Larsen shelf (Fig. 1b). If the GZWs were related to ice-sheet advance, then MSGLs would be expected to be continuous across them because both grounding-zone sediments, and subglacial till further upstream, are transported down-flow to form an extensive till unit across the shelf similar to that on the western Antarctic Peninsula continental shelf (Ó Cofaigh et al. 2005).

Dating of the transition from grounded ice to ice shelf in the inner Larsen-A area indicates it is likely that the grounding zone of the retreating APIS reached the shelf adjacent to Larsen Inlet before $10.7 \mathrm{ka}$ ago (Brachfeld et al. 2003). The lobe-shaped and streamlined nature of the GZWs, coupled to the presence of MSGLs over the surface or up-flow of them, indicates that ice-flow remained active during retreat and stillstands, and continued to transport subglacially deformed sediment to, and shape landforms at the margin. Punctuated retreat of the APIS across the shelf south of the Larsen Inlet contrasts with rapid recession through deeper bathymetric troughs of the Antarctic Peninsula and other polar shelves due to differences in local bathymetry, climate and drainage-basin size (Evans et al. 2005; Dowdeswell et al. 2008).

\section{References}

BRACHFELD, S., DOMACK, E., KISSEL, C., LAJ, C., LEVENTER, A., ISHMAN, S., GILBERT, R., CAMERLENGHI, A., \& EGLINTON, L.B., 2003. Holocene history of the Larsen-A Ice Shelf constrained by geomagnetic paleointensity dating. Geology, 31, 749 752.

DOWDESWELL, J.A., OTTESEN, D., EVANS, J., Ó COFAIGH, C. \& ANDERSON, J.B. 2008. Submarine glacial landforms and rates of ice-stream collapse. Geology, 36, 819 - 822.

DOWDESWELL, J.A. \& FUGELLI, 2012. The seismic architecture and geometry of grounding-zone wedges formed at the marine margins of past ice sheets. Bulletin of the Geological Society of America, 124, 1750 - 1761.

EVANS, J., PUDSEY, C.J., Ó COFAIGH, C., MORRIS, P.W. \& DOMACK, E.W. 2005. Late Quaternary glacial history, dynamics and sedimentation of the eastern margin of the Antarctic Peninsula Ice Sheet. Quaternary Science Reviews, 24, 741 - 774.

HORGAN, H.J., CHRISTIANSON, K., JACOBEL, R.W., ANANDAKRISHNAN, S., ALLEY, R.B., 2013. Sediment deposition at the modern grounding zone of Whillans Ice Stream, West Antarctica. Geophysical Research Letters 40, 3934 - 3939.

Ó COFAIGH, C., DOWDESWELL, J.A., ALLEN, C.S., HIEMSTRA, J., PUDSEY, C.J., EVANS, J. \& EVANS, D.J.A. 2005. Flow dynamics and till genesis associated with a marinebased Antarctic palaeo-ice stream. Quaternary Science Reviews, 24, 709-740.

OTTESEN, D., RISE, L., KNIES, J., OLSEN, L. \& HENRIKSEN, S. 2005. The VestfjordenTrænadjupet palaeo-ice stream drainage system, mid-Norwegian continental shelf. Marine Geology, 218, 175 - 189. 
SHIPP, S.S., ANDERSON, J.B. \& DOMACK, E.W. 1999, Late Pleistocene-Holocene retreat of the West Antarctic Ice-Sheet system in the Ross Sea: Part 1 - Geophysical results. Geological Society of America Bulletin, 111, 1486-1516.

Fig.1. Multibeam bathymetry and cross-profiles of grounding-zone wedges (GZWs) on the northern Larsen continental shelf, NE Antarctic Peninsula. (a) Image showing numerous grounding zone wedges and subglacially-generated mega-scale glacial lineations (MSGLs) on the continental shelf to the south of Larsen Inlet and east of inner Larsen-A. The background satellite image is from Landsat 7 (15 December 2001). GZWs are found in water depths of 510 - 580 m. Acquisition system Kongsberg EM120. Frequency 12 kHz. Grid-cell size 25 m. (b) Greyscale image representing an enlarged sub-area of Fig. 1a (box labelled as b in Fig. 1a), showing streamlined GZWs and MSGLs. One set of MSGLs extend across, and terminate at, or short distance from, the outer face of the grounding zone wedges (marked by red arrows). A second set of MSGLs extend shelfwards away from the base of the GZWs (marked by light blue arrows). (c - e) Bathymetric profiles of the seafloor along three transects (Lines 1, 2 and 3 in Fig. 1a, b) across three grounding zone wedges (GZW1 - GZW3 in Fig. 1a, b). (f - g). 3.5 kHz sub-bottom profiles across wedges GZW2 and GZW3 (x-x' and in y-y' Fig. 1a). Note the acoustically transparent sedimentary nature of the sub-seafloor. Acquisition system Kongsberg TOPAS PS 018 parametric sub-bottom profiler. Secondary beam frequency 0.5-6 kHz. (h) Location map showing the study area (red box); map from IBCAO Version 3.0. 

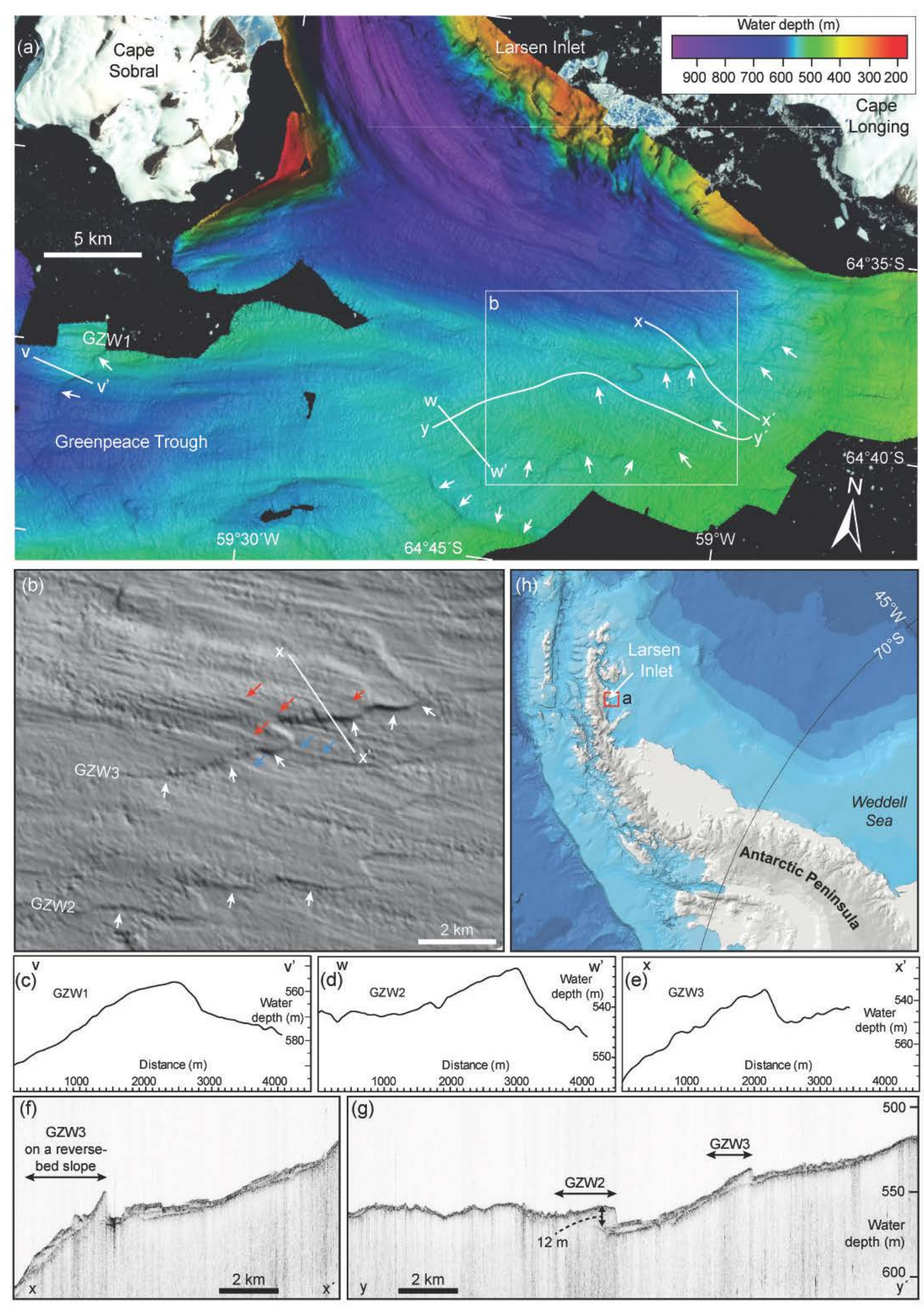

Figure 1 